\title{
The Epithelial-Mesenchymal Transition Influences the Resistance of Oral Squamous Cell Carcinoma to Monoclonal Antibodies via Its Effect on Energy Homeostasis and the Tumor Microenvironment
}

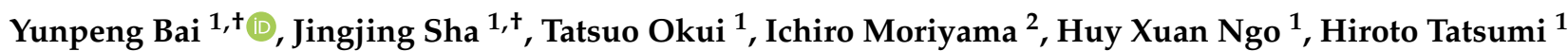 \\ and Takahiro Kanno ${ }^{1, *}$
}

1 Department of Oral and Maxillofacial Surgery, Shimane University Faculty of Medicine, Izumo, Shimane 693-8501, Japan; xyywq@126.com (Y.B.); jsswjbnjw@gmail.com (J.S.); tokui@med.shimane-u.ac.jp (T.O.); ngoxuanhuy158@gmail.com (H.X.N.); tatsumi@med.shimane-u.ac.jp (H.T.)

2 Department of Medical Oncology/Innovative Cancer Center, Shimane University Hospital, Izumo, Shimane 693-8501, Japan; ichimori@med.shimane-u.ac.jp

* Correspondence: tkanno@med.shimane-u.ac.jp; Tel.: +81-(0)853-20-2301; Fax: +81-(0)853-20-2299

+ These authors contributed equally to this paper.

\section{check for} updates

Citation: Bai, Y.; Sha, J.; Okui, T.; Moriyama, I.; Ngo, H.X.; Tatsumi, H.; Kanno, T. The Epithelial-

Mesenchymal Transition Influences the Resistance of Oral Squamous Cell Carcinoma to Monoclonal Antibodies via Its Effect on Energy Homeostasis and the Tumor Microenvironment. Cancers 2021, 13, 5905. https:// doi.org/10.3390/cancers13235905

Academic Editor: Marilena Vered

Received: 20 October 2021

Accepted: 20 November 2021

Published: 24 November 2021

Publisher's Note: MDPI stays neutral with regard to jurisdictional claims in published maps and institutional affiliations.

Copyright: (C) 2021 by the authors Licensee MDPI, Basel, Switzerland. This article is an open access article distributed under the terms and conditions of the Creative Commons Attribution (CC BY) license (https:/ / creativecommons.org/licenses/by/ $4.0 /)$.
Simple Summary: Developing therapeutic resistance to monoclonal antibodies (mAbs) causes increasing failure in oral squamous cell carcinoma (OSCC) treatment. A clear understanding of the molecular basis for drug resistance will pave the way for OSCC management and a new effective therapeutic modality. This review elucidates the role played by EMT during the emergence of mAbs resistance and the configuration of the tumor microenvironment. The cancer cells that undergo the EMT process also cause significant energy substrate consumption which leads to a limited number and function of effective T-cells, eventually leading to immune evasion. This review firstly reveals the implicit crosstalk between the EMT, energy metabolism, and therapeutic resistance of mAbs. A focus on the rebalanced energy homeostasis in cancer cells and T-cells may provide a new perspective on the treatment of OSCC.

Abstract: Oral squamous cell carcinoma (OSCC) is a major type of cancer that accounts for over $90 \%$ of all oral cancer cases. Recently developed evidence-based therapeutic regimens for OSCC based on monoclonal antibodies (mAbs), such as cetuximab, pembrolizumab, and nivolumab, have attracted considerable attention worldwide due to their high specificity, low toxicity, and low rates of intolerance. However, the efficacy of those three mAbs remains poor because of the low rate of responders and acquired resistance within a short period of time. The epithelial-mesenchymal transition (EMT) process is fundamental for OSCC growth and metastasis and is also responsible for the poor response to mAbs. During EMT, cancer cells consume abundant energy substrates and create an immunosuppressive tumor microenvironment to support their growth and evade $\mathrm{T}$ cells. In this review, we provide an overview of the complex roles of major substrates and signaling pathways involved in the development of therapeutic resistance in OSCC. In addition, we summarize potential therapeutic strategies that may help overcome this resistance. This review aims to help oral oncologists and researchers aiming to manage OSCC and establish new treatment modalities.

Keywords: oral squamous cell carcinoma; chemotherapeutic monoclonal antibodies; cetuximab; pembrolizumab; nivolumab; epithelial-mesenchymal transition; tumor microenvironment

\section{Introduction}

Oral squamous cell carcinoma (OSCC), the main pathological type of oral cancer (OC), accounts for at least $90 \%$ of cases of oral malignancy [1]. Although there have 
been many developments in cancer treatment, the overall 5-year survival rate for OSCC remains low, at $\sim 50-60 \%$ [2]. The standard treatments for OSCC are surgery, radiotherapy, and chemotherapy. Unfortunately, adjuvant therapies such as chemotherapy do not achieve satisfactory results, largely due to low target selectivity, severe side effects, and drug resistance. Numerous studies have demonstrated that cancer cells tend to develop chemoresistance after frequent use of high-dose chemotherapy [3].

Several phenomena, including the epithelial-mesenchymal transition (EMT) and the accumulation of cancer stem cells (CSCs) and cancer-associated fibroblasts (CAFs), are implicated in chemoresistance in OSCC [4]. The EMT is a common feature of various types of cancer and is closely associated with CSCs and CAFs. During the EMT, a change occurs in the molecular pathways of cancer cells, and gene reprogramming induces their proliferation and invasiveness. Invasive cancer cells acquire mesenchymal features by gradually losing cell polarity, tight intercellular junctions, and the ability to express epithelial markers [5]. Numerous EMT-activating transcription factors (EMT-ATFs) participate in this process, including Snail, TWIST, and ZEB. The EMT-ATFs specifically bind to the promoter of E-cadherin through E-boxes and eventually suppress the expression of the adherent junction protein E-cadherin [6]. The balance between the epithelial marker Ecadherin and mesenchymal markers plays a pivotal role in the dynamic EMT process, which affects subsequent cancer cell migration, metastasis, immune evasion, and resistance to chemotherapeutic agents [7].

While primary tumor cells undergo EMT, those cells create an optimal tumor microenvironment (TME) by secreting various cytokines and proteases to facilitate their survival and ability to evade the immune system. Stromal cells, which are affected by the TME, are also activated to release several factors that trigger the EMT in primary tumor cells [8]. Methods to inhibit the EMT and convert the TME into a normal stromal cell microenvironment are needed.

Another problem for conventional chemotherapy is that cancer cells share similarities with normal host cells, so it is difficult for therapeutic agents to achieve high levels of selective cytotoxicity. However, in the last decade, monoclonal antibodies (mAbs) have shown great potential for use against many hematological and solid cancers in humans [9]. The mAbs target cancer cells by specifically binding to cell surface antigens that are necessary for cell proliferation or differentiation, or for immune meditation. Examples of such antigens include the epidermal growth factor receptor (EGFR), programmed cell death protein 1 (PD-1), cytotoxic T-lymphocyte-associated protein 4 (CTLA-4), and vascular endothelial growth factor and its receptor (VEGF and VEGFR, respectively) [10-12].

According to the National Comprehensive Cancer Network, only three mAbs, cetuximab, pembrolizumab, and nivolumab, have been used as evidence-based therapeutic regimens of $\mathrm{mAbs}$ for treating OSCC [13]. Although this new therapeutic approach offers many advantages, it also has several limitations, including adverse effects and the development of resistance, in addition to the high cost of producing the antibodies [14]. The development of resistance against mAbs, also seen in some OSCC patients, particularly when used alone without other chemotherapeutic agents, remains problematic [15]; nevertheless, the engineering of $\mathrm{mAbs}$ represents a major milestone in cancer therapeutics. To address this issue, we focused on the molecular pathways, proteins, and genes that participate in the key processes that contribute to the development of resistance to mAbs in OSCC patients, including the EMT process and energy metabolic homeostasis. Furthermore, we proposed a hypothesis regarding the latent mechanisms involved in the development of drug resistance to facilitate the identification of potential treatment targets. We concluded that, with concerted global efforts, the breadth and quality of treatment approaches using mAbs should improve significantly. A more specific, less toxic, and more cost-effective $\mathrm{mAb}$ will benefit OSCC patients worldwide. 


\section{Cetuximab: A mAb and EGFR Inhibitor}

\subsection{Rapid Response of Cancer Cells to Cetuximab Treatment}

Cetuximab, an IgG1 mAb, is an inhibitor of EGFR. It is used for the treatment of locoregionally advanced, metastatic, and recurrent cancers, including OSCC [16]. Compared to EGF, cetuximab has a 5-fold higher affinity for EGFR, so can bind to EGFR prior to EGF and block the interaction of the ligand with its receptor [17].

EGFR, also known as ErbB1 or HER1, is a transmembrane tyrosine kinase receptor that binds to the EGF family of extracellular protein ligands. EGF stimulates OSCC cells to undergo the EMT. Up to $90 \%$ of OSCC cells overexpress EGFR. Upregulated EGFR is associated with poor prognosis, chemoresistance, and radioresistance [18]. Cetuximab seemed to be a reasonable therapeutic strategy for OSCC, however, very few patients responded to the treatment, and virtually all responders developed resistance within a short period [19].

Based on the work of Kagohara et al. [20], a cetuximab-treated cell line developed an early transcriptional response (within one day), and EGFR inhibition therapy induced a significant transcriptional variation within five days compared to untreated cells. EGFR inhibition therapy disrupts the homeostasis of cancer cells; therefore, the cells spontaneously progress to a state with activated heterogenetic hallmark pathways to overcome EGFR inhibition. This could explain the immediate upregulation of vimentin seen when cells were treated with cetuximab [20].

As well as vimentin, other EMT-ATFs such as LEF1, TWIST1, and ZEB1 were significantly increased after treatment with cetuximab. Gene analysis of the same patients showed that Wnt, TGF- $\beta$, and NOTCH1 pathway-related genes were significantly upregulated following treatment with cetuximab. All of those genes were specifically involved in the extracellular matrix organization, including cell adhesion, migration, and the inflammatory response [21]. Five CAFs-associated genes, CXCL12, ACTA2, FAP, PDGFRB, and S100A4, were also significantly upregulated in the cetuximab-treated group compared to the control group. CXCL12, also known as stromal cell-derived factor- $1 \alpha$, binds to its receptor CXCR4 and activates the CXCR4/CXCL12 axis; this leads to tumor proliferation, vascularization, and metastasis [22]. Activation of the CXCR4/CXCL12 axis has been shown to decrease the levels of E-cadherin and increase those of vimentin and N-cadherin (Figure 1). These findings imply that cetuximab may induce the EMT indirectly, as well as CAFs proliferation, leading to the development of cancer cell resistance. The CXCR4 is expressed in multiple cell types, including lymphocytes, hematopoietic stem cells, epithelial cells, and cancer cells [23]. A recent study has demonstrated that CXCR4 may also play a role in CSCs in OSCC [24]. Inhibitors of the CXCR4/CXCL12 axis are currently under development [25]. 


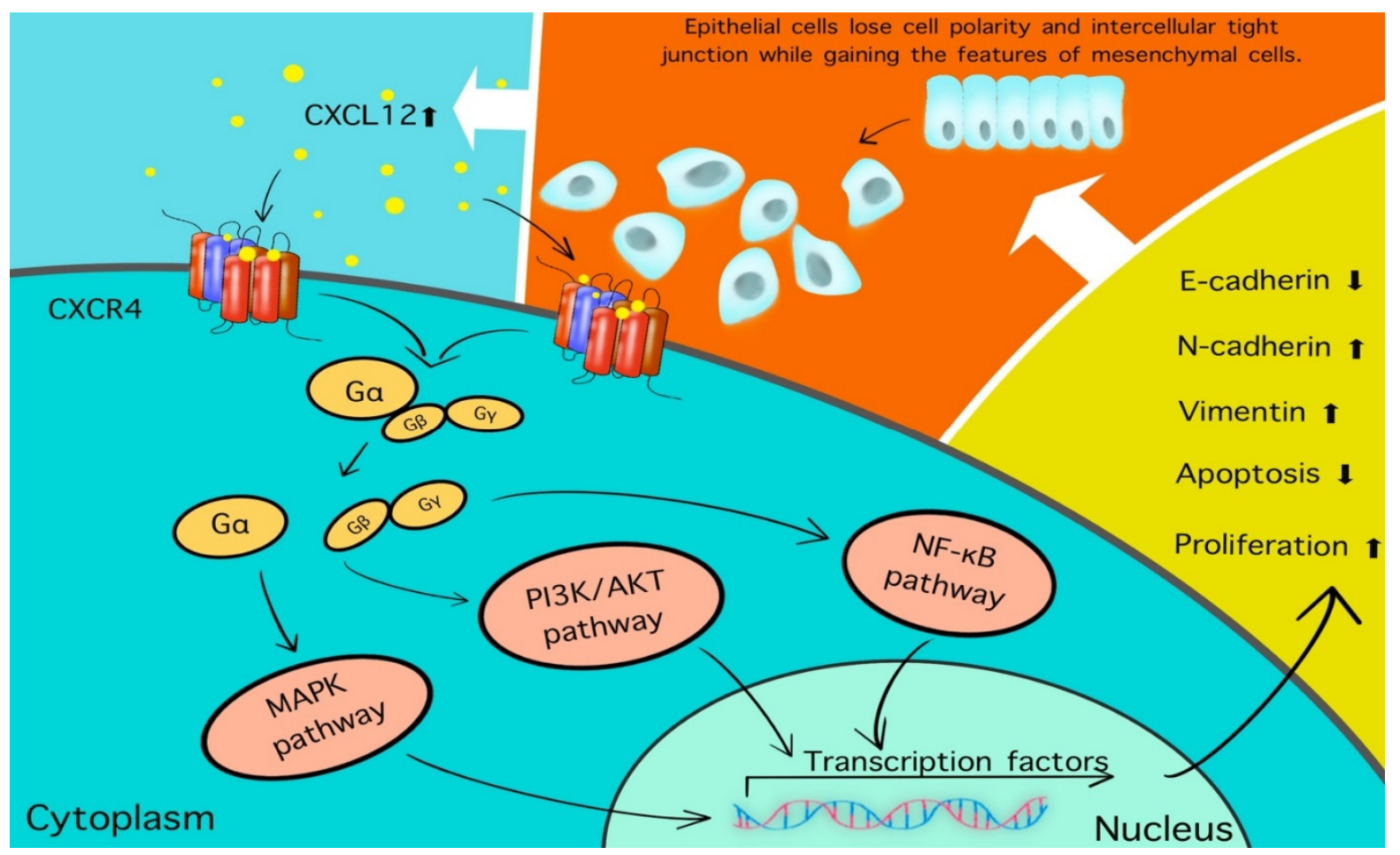

Figure 1. CXCR4, one of the receptors of CXCL12, is expressed on multiple cell types, including lymphocytes, hematopoietic stem cells, epithelial cells, and cancer cells [26]. The binding of CXCL12 to CXCR4 results in the activation of the CXCR4/CXCL12 axis and dissociation of the heterotrimeric protein complex (G $\alpha \beta \gamma)$ to G $\alpha$ and G $\beta \gamma$ subunits, which activate a number of signaling pathways including MAPK, PI3K/AKT, and NF- $\mathrm{KB}$. Ultimately, cell growth, protein synthesis, and inflammation are upregulated. In addition to this change, the E-cadherin will be decreased and the expression of $\mathrm{N}$-cadherin and vimentin will be raised; simultaneously, those cells lose cell polarity and tight intercellular junction while gaining the features of a mesenchymal cell and the capability of migration and invasion. This positive feedback loop stimulates more CXCL12 to be released into the TME to activate the CXCR4/CXCL12 axis.

\subsection{Cetuximab Mainly Targets OSCC with Epithelial Features}

In one study, cetuximab failed to block EGF-driven mesenchymal progression in transformed OSCC [27], suggesting a novel drug resistance mechanism. An earlier study reported that esophageal squamous cell carcinoma (ESCC) cells with mesenchymal features displayed resistance not only to cetuximab but also to tyrosine kinase inhibitors (TKIs) such as erlotinib, albeit that both drugs were highly effective against ESCC cells with epithelial features [28].

The progression of OSCC is always associated with the release of extracellular vesicles (EVs) from cancer cells into the milieu. The EVs usually contain CD9 and EGFR [29]. Earlier research showed that CD9-positive EVs were secreted more often by OSCC than epithelial cells [30]. Fujiwara et al. [31] reported that the transformation of normal epithelial cells into spindle phenotype cells triggered by EVs secreted by OSCC was blocked by cetuximab, both the expression of vimentin and levels of EGFR were also downregulated simultaneously. Therefore, we hypothesized that cetuximab primarily targets EV-secreting cancer cells, especially those with epithelial features rather than the completely transformed mesenchymal cancer cells. This phenomenon could lead to new therapeutic strategies.

Most anti-tumor drugs target a single oncogenic signal or phase. However, during the EMT, the signaling pathways and features of cancer cells are completely different among the "epithelial", "mesenchymal", and "transition" stages. Therefore, instead of using single drug treatment that inevitably results in the development of resistance or recurrence, multiple agents that tackle various pathways may yield better results. 


\subsection{Combination Treatment with Cetuximab}

An effective regimen for refractory OSCC is the combination of cetuximab and cisplatin. Several studies have demonstrated that this combination is beneficial in terms of the tumor response and survival rate compared to single therapeutic agents [32,33].

It was proposed that cetuximab initiates cytoplasmic signaling through the autophosphorylation of intracellular domains [34]. Phosphorylated EGFR activated the MAPK and PI3K/AKT/mTOR pathways, which are also involved in the therapeutic effects of cisplatin [35]. However, cisplatin also induces cell apoptosis through the activation of the mitochondrial signaling pathway and AMP-activated protein kinase signaling pathway (AMPK) [36]. AMPK is a serine/threonine kinase that regulates intracellular energy homeostasis. The activation of the AMPK pathway could rapidly reprogram glucose metabolism, inducing cells to switch from active ATP consumption to ATP production to restore energy, potentially reversing the Warburg effect [37].

Cetuximab has been reported to have higher efficacy against K-RAS-type cancer cells than cells harboring a K-RAS mutation [38]. As a molecular switch, activated KRAS is vital for stimulating the downstream signaling cascade via the Raf/MEK/ERK and $\mathrm{PI} 3 \mathrm{~K} / \mathrm{AKT} / \mathrm{mTOR}$ pathways after extracellular ligands, such as EGF, bind to the membrane receptor [39]. In OSCC patients, K-RAS frequently mutates into H-RAS, although the reason for this is unknown (this mutation is frequently detected in smokers and betel quid-chewing individuals [40]). Previous studies have demonstrated that the H-RAS mutation plays a crucial role in treatment failure and the development of resistance to cetuximab in OSCC, by stimulating downstream genes like c-MYC, BCL-XL, and BCL2 [41]. Accordingly, we hypothesized that regulating AMPK levels may compensate for the cetuximab resistance caused by the K-RAS mutation. A study of colorectal cancer strongly supports this hypothesis [42], but whether the same mechanism occurs in OSCC remains to be proven.

The interaction between cetuximab and cisplatin may explain why these two drugs provide better outcomes in combination than either alone. Both drugs reciprocally affect the mitochondrial activity and energy homeostasis in cancer cells. During the EMT process, the cells require tremendous amounts of energy; to counteract the effect of the drugs, to switch from mitochondrial oxidative phosphorylation to cytosolic glycolysis to enable the EMT to be completed in a timely manner, and to build up sufficient biomass (by suppressing apoptosis and evading immunity) for resistance to anticancer therapy [43]. The Warburg effect may trigger the EMT and accelerate the glycolytic metabolism to generate sufficient ATP [44]. Lin et al. reported that when the respiratory enzyme citrate synthase (CS) was knocked down in HeLa cells, the expression of EMT-ATFs such as Snail and TWIST increased, and the MAPK signaling pathway was activated [45]. This EMT phenotype induced by CS knockdown was modulated by ATP treatment and partially reversed by the suppression of the MAPK pathway.

Altered energy homeostasis in association with the EMT may be responsible for resistance to cetuximab. Currently, there are no therapeutics specifically targeting the RAS mutation to restore energy homeostasis in cancer cells. An early study reported that tipifarnib, a farnesyltransferase inhibitor, competes with RAS and, thus, suppresses its activity; however, this effect is non-specific as other proteins such as centromeric proteins were also inhibited [46].

Although cetuximab has a strong anti-tumoral effect, only certain types of cancer cells respond to it. Unfortunately, OSCC patients with K-RAS mutations do not respond to cetuximab. However, combining cetuximab with other antitumor drugs greatly improves the overall response rate; therefore, oral oncologists should consider this strategy.

\section{Immune Checkpoint Inhibitors}

\subsection{PD-1-Blocking Agents: Pembrolizumab and Nivolumab}

One of the hallmarks of cancer is that the immune system does not mount an effective antitumor response [47]. The PD-1 receptor is mainly expressed on the surface of T cells [48]. 
When PD-1 binds to its ligands, including PD-L1 and PD-L2, the activation of cytotoxic $\mathrm{T}$ cells (CD8+ T cells) is inhibited [49]. Cancer cells can, thus, evade the T cell-induced antitumor activity.

Pembrolizumab was developed to block the interaction of PD-1 with its ligands and inhibit immune evasion. Pembrolizumab is a highly selective monoclonal IgG4 isotype antibody that impedes inhibitory signals in T cells [50]. This antibody was first approved in the United States in 2014 [51] as a first-line treatment for metastatic bladder cancer patients with high levels of PD-L1 and resistance to cisplatin-based treatment. In patients with OSCC/head and neck squamous cell carcinoma (HNSCC), pembrolizumab is used as a second-line treatment after platinum-based chemotherapy.

Nivolumab is another human IgG4 PD-1 immune checkpoint inhibitor antibody that blocks PD-L1 by binding to PD-1 [52]. Both pembrolizumab and nivolumab have been approved for patients with recurrent/metastatic OSCC who have previously undergone platinum-based chemotherapy [53].

As an immune checkpoint inhibitor, nivolumab can achieve similar clinical outcomes to pembrolizumab [54]. The two drugs have different affinity sites and bind to different epitopes of the same receptor; however, the difference in pharmacokinetics between these two drugs remains to be elucidated [55].

PD-1 binding of pembrolizumab is dependent on a flexible $\mathrm{C}^{\prime} \mathrm{D}$ loop, while nivolumab targets PD-1 via the N-terminal extension and FG and BC loops (Figure 2). In a previous study of the crystal structure of pembrolizumab and nivolumab, the epitope region of the former was shown to have a much great affinity area to the PD-1 binding site than the latter [55]. Intriguingly, the binding sites of these two drugs on the PD-1 molecule do not overlap. These results imply that the two antibodies could act synergistically, thus, raising the question of whether they should be co-administered. Preclinical and early clinical data indicate that pembrolizumab and nivolumab can be used interchangeably [56].

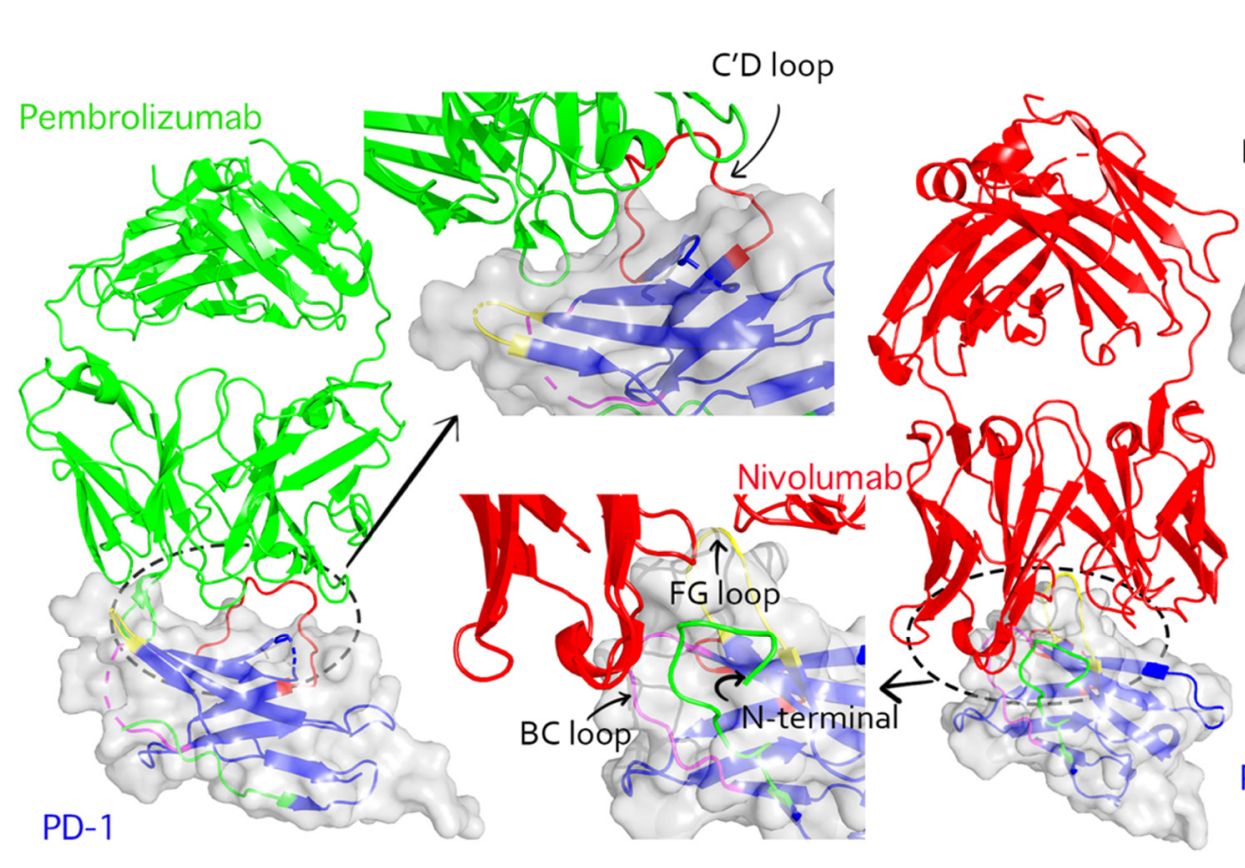

A

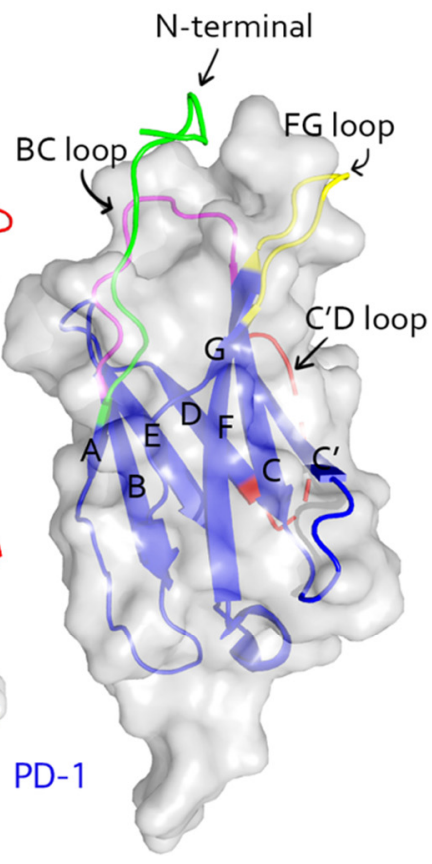

C

Figure 2. Structural interactions of pembrolizumab and nivolumab with PD-1. (A): Pembrolizumab complexed (PDB ID: 5jxe) with human PD-1 extracellular domain. The light green ribbons represent pembrolizumab. PD-1 is represented by the transparent blue ribbons. (B): The complex of nivolumab (PDB ID: 5wt9) and PD-1 extracellular domain; the nivolumab is represented by red ribbons. (C): The extracellular domain of human PD-1 (PDB ID: 3rrq). The BC loop, C'D loop, FG loop, and N-terminal domain are in magenta, red, yellow, and green colors, respectively. 


\subsection{EMT-ATFs Participate in the Configuration of an Immunosuppressive TME}

Compared to conventional chemotherapy, the overall survival rate of all cancer patients receiving immunotherapy is significantly higher. However, $30-50 \%$ of patients remain unresponsive or less responsive to PD-1 blockade therapy [57].

A few patients initially responded to PD- 1 blockade therapy but later became unresponsive, possibly due to insufficient effector T cells [58]. In another study, patients were unresponsive from the start of the treatment [59]. A recent study reported that in lung adenocarcinoma, the levels of multiple immune checkpoint molecules, including PD-L1, were increased, reflecting an EMT phenotype. This suggested that EMT could be associated with immunosuppressive TME changes $[60,61]$. The EMT-ATFs not only interact with the regulatory networks of microRNAs to promote cancer cell plasticity and maintain cancer stemness but also play an essential role in configuring the TME [62].

In the TME, Snail induces stromal cells to undergo the EMT, which increases the expression of immunosuppressive cells (such as CD4+ Foxp3+ Treg-like cells) [63]. Snail was also found to induce the upregulation of chemokines such as CCL2 and CXCL2, subsequently promoting the generation of immunosuppressive dendritic cells (DCs), Treg cell infiltration, and the inhibition of CD8+ T cells. Under hypoxic conditions, cancer cells can also secrete several chemokines that inhibit CD4+ and CD8+ T cell function [64], thus, establishing an immunosuppressive environment [65].

TWIST is another transcription factor with immunosuppressive activities. It upregulates PD-L1, which promotes the EMT and carcinogenesis in skin SCC [66]. TWIST was also reported to downregulate NF- $\mathrm{KB}$ and TNF- $\alpha$, thereby regulating inflammatory suppression through type I interferons (IFNs) [67]. ZEB1 and ZEB2 were found to be involved in the activation of DCs and immune evasion in cancer [68].

\subsection{Interactions among Energy Metabolism, Immunosuppression, and the TME}

In addition to the EMT-ATFs, a complex regulatory network consisting of noncoding RNAs, epigenetic modifiers, post-translational regulators, and alternative splicing factors has been implicated in the dynamic regulation of the TME $[69,70]$. All of these extracellular factors promote a hypoxic, acidic, and inflammatory TME. Immune cells in the TME secrete cytokines, inflammatory factors, and chemokines to drive the EMT in cancer cells. In turn, cancer cells interact with immune cells to promote cell plasticity and the release of immunosuppressive substances or cytokines, which induce the infiltration of Treg cells or polarized M2 macrophages into the TME; therefore, an immunosuppressive microenvironment is generated, promoting cancer genesis and therapeutic resistance.

Cancer cells predominantly undergo glycolytic metabolism, which facilitates the rapid generation of ATP and inevitably leads to the accumulation of lactic acid in the milieu. $\mathrm{T}$ cells are similar to cancer cells in terms of their ability to recognize tumor antigens. To meet the bioenergetic demand for rapid proliferation, $\mathrm{T}$ cells also switch to glycolytic energy metabolism. Distinct from cancer cells, $\mathrm{T}$ cells produce pyruvic acid rather than lactic acid as the byproduct of glycolysis [71]. In accordance with the similar proliferation profile between cancer and T cells, the cells compete for energy sources and substrates for anabolic pathways. Several studies have demonstrated that glucose and tryptophan were excessively consumed by tumor cells, thereby restricting $\mathrm{T}$ cell glycolytic metabolism, activation, and proliferation, which eventually led to $\mathrm{T}$ cell dysfunction or depletion [72,73]. As a consequence, infiltration of $\mathrm{T}$ cells into the tumor mass was severely reduced. Furthermore, there was a decrease in the nuclear factor of activated $\mathrm{T}$ cells and natural killer (NK) cells, and in IFN- $\gamma$ in the TME. These changes permitted cancer cells to escape from antitumor immunity [74].

Energy metabolism is mainly regulated by two completely opposing energy sensors: AMPK and mTOR [75]. The AMPK pathway regulates mitochondrial catabolism under restricted energy and nutrient conditions. However, the mTOR pathway (mainly mTOR complex 1, mTORC1) preferentially triggers anabolic metabolism [76,77]. Zhang et al. revealed that mTORC1 inhibitors activated the AMPK pathway, suppressed the EMT 
process, and downregulated PD-L1 expression in lung cancer [78]. In another report, the upregulated expression of PD-L1 was observed predominantly in patients with K-RAS mutations [79]. The overexpression of RAS promoted the progression of EMT by decreasing E-cadherin and increasing the expression of TGF $\beta$, vimentin, and Snail, most likely via the MAPK and PI3K/AKT/mTOR pathways in concert with mTORC1.

Accordingly, we hypothesized that the upregulation of PD-L1 is correlated with cell energy metabolism (regulated by mTORC1) in the up and downstream pathways. Kumar et al. [58] suggested that enhanced activity in the mitochondrial metabolic pathway of CD8+ T cells may affect the PD-1 blockade. Therefore, it may be useful to explore ways to improve the precision of the mitochondrial function of CD8+ T-cells.

\section{Summary}

In 1997, rituximab became the first $\mathrm{mAb}$ to be approved for treating cancer and proven effective for the treatment of non-Hodgkin's lymphoma. Following this success, numerous mAbs have been developed and used for the treatment of various human cancers [80]. Activated EGFR and its downstream signaling pathways were implicated in the proliferation, apoptosis suppression, invasion, and angiogenesis of cancer cells [81]. Compared to hematological cancers, solid tumors such as OSCC had more than $80 \%$ higher EGFR expression levels [82,83]. That may explain why cetuximab, as a novel treatment of OSCC, has garnered considerable attention since 2004 and has been approved for clinical use in Europe and the USA [84]. However, long-term use of cetuximab for OSCC often leads to drug resistance, and an improvement in the overall survival time of only 2.7 months compared to conventional chemotherapy alone $[17,85,86]$.

In 2016, the FDA approved the use of pembrolizumab and nivolumab in patients with platinum-resistant OSCC; however, less than $20 \%$ of the patients responded well to those immunotherapies [87]. Moreover, approximately $50 \%$ of patients with OSCC are in a late stage of disease and the 5-year survival rate remains below $60 \%$ [88,89]. The treatment options for OSCC patients are limited, particularly for advanced patients who are refractory to chemotherapy. It is imperative to better understand the molecular mechanisms underlying drug resistance so that more effective therapies can be developed.

In OSCC, precancerous mutations may develop in cells remote from the original tumor [90]. This is known as field cancerization, whereby oral epithelial dysplasia and oral intraepithelial neoplasia patients may progress to OSCC [91]. Premalignant cells, over surgical margins, may develop into secondary tumors differing in clonality from the primary tumor [90].

Premalignant cells can trigger the EMT, and release chemokines and transcriptional factors to create a low-energy, hypoxic, and immunosuppressive TME to promote their survival. This environment then activates the AMPK pathway [92]. The activation of AMPK increases cell catabolism, and decreases anabolism, through the phosphorylation of key proteins in several pathways, including mTORC1 [93]. AMPK is an attractive therapeutic target in many diseases, including cancer and type II diabetes. Under energy-depleted conditions, the activation of AMPK leads to a decrease in mTORC1 activity, which retards cell growth and protein synthesis.

The mTORC1 exerts opposing effects on AMPK (Figure 3) [94]. When growth factors such as EGF and VEGF bind to their tyrosine kinase receptor on the cell membrane, the PI3K/AKT pathway is activated. Furthermore, phosphoinositide-dependent kinase-1 activates AKT and mTORC1, which prompts the entire pathway to enhance cell proliferation. The MAPK pathway is also activated by these growth factors. Cytosolic glycolysis and protein synthesis are enhanced, which provides more energy and, thus, promotes cancer cell survival. As a member of the stress-activated protein kinase family, p38 is activated during the energy depletion phase [93]. Interactions among p38, AKT, and NF- $\mathrm{kB}$, trigger the downstream expression of mTORC1, leading to an accumulation of reactive oxygen species (ROS) and DNA damage (Figure 4) [95]. 


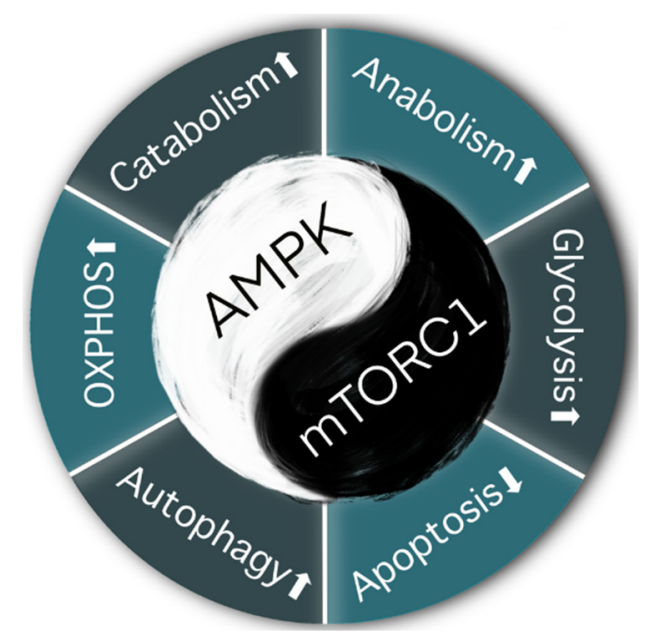

Figure 3. AMPK and mTORC1 are components of conserved pathways that evolved via a yin-yanglike antagonistic mechanism controlling catabolism and anabolism [94]. The AMPK pathway prompts cell autophagy and regulates catabolic metabolism and oxidative phosphorylation (OXPHOS) under restricted nutrient and energy conditions. The mTOCR1 pathway preferentially activates anabolic metabolism and glycolysis, while suppressing cell apoptosis [58].

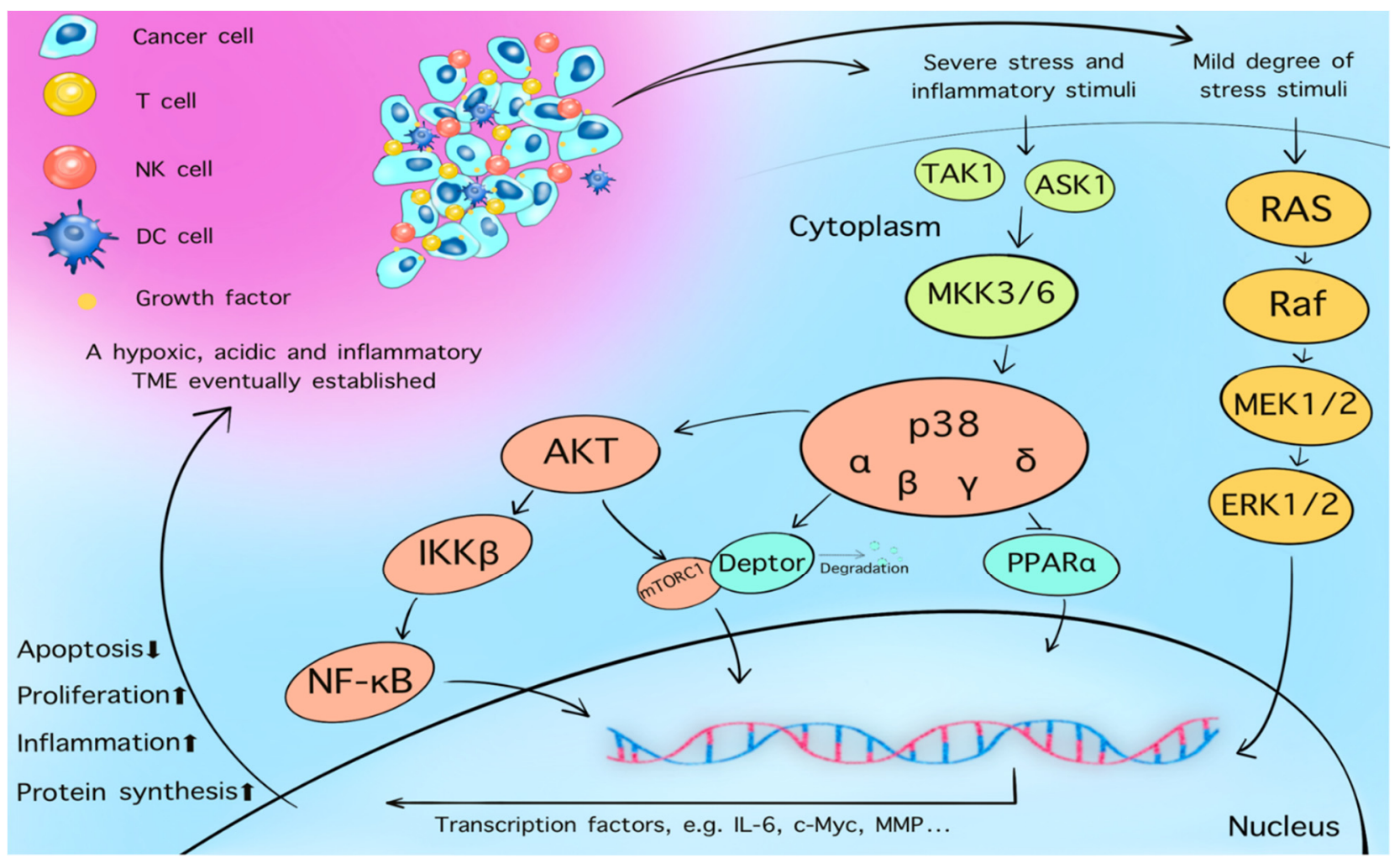

Figure 4. Four p38 subfamilies have been identified: $p 38-\alpha,-\beta,-\gamma$, and $-\delta$ [96]. MAPK cascade is the main mechanism by which the four p38 isoforms are activated in human cells [97]. Protein kinase activity of p38 is stimulated by oncogenic TAK1 or ASK1 through its downstream mitogen-activated protein kinase kinases, MKK3 and MKK6, under conditions of severe stress and inflammation (under mild stress, the ERK/MAPK pathway is activated) [98]. Activated p38 also interacts with AKT and NF- $\mathrm{BB}$, triggering downstream mTORC1 via the degradation of DEPTOR, or by suppressing the activation of $\operatorname{PPAR} \alpha[95]$. These changes promote cell proliferation, inflammation, protein synthesis, and decrease apoptosis, ultimately leading to a hypoxic, acidic, and inflammatory TME. 
The overall response rate to the EGFR inhibitor cetuximab varies dramatically among patients and cannot be predicted based on EGFR binding alone. Whether the downstream pathway is normally regulated by K-RAS, but not by another mutated RAS, is an important consideration. In OSCC patients, mutations are most common in K-RAS genes, including H-Ras and N-Ras; these mutations were detected in over $30 \%$ of patients with OSCC in Southeast Asia [99]. Mutated K-RAS genes can activate the MAPK and PI3K/AKT/mTOR pathways, and regulate the expression of mTORC1; ultimately, OSCC cells become resistant to cetuximab.

Such resistance can also develop to PD-1 blockers. Although pembrolizumab and nivolumab can both interact with PD-1 to activate T cells, higher energy consumption by CD8+ T cells and a lower concentration of energy substrates in the TME increase the anabolism of T cells; this mainly depends on the activation of the mTORC1 pathway. Increased p38 and ROS accumulation further damages the mitochondria in T cells, leading to an exhausted state [58]. The PD-1 blockade ultimately shortens the life span of T cells. Furthermore, the elimination of T cells from the cancer field (by over-activating them) may explain why most OSCC patients show an excellent initial response to pembrolizumab/nivolumab, but subsequently become unresponsive [100].

\section{A potential Novel Combination Therapy}

In this review, we showed that the EMT, which leads to a newly configured TME and altered cell homeostasis, must be considered when developing novel treatments for OSCC. Combining several anti-tumor drugs, which represents the current strategy, is not effective over the long term.

\subsection{Combined Use of the Small-Molecule Inhibitors MEK}

Blocking the PI3K/AKT/mTOR and MAPK pathways by small-molecule inhibitors may be effective for treating OSCC. To date, four small-molecule MEK inhibitors have been approved by the FDA: trametinib, selumetinib, cobimetinib, and binimetinib [101]. Several other inhibitors are also under development, such as PD184352 [102] and PD0325901 [103]. A recent open-label, three-arm phase III trial evaluated the safety and efficacy of encorafenib and cetuximab, with or without binimetinib, for treating patients with BRAFV600E (a gene that encodes B-Raf)-mutated colorectal cancer. The overall response rates were $26 \%, 20 \%$, and $2 \%$ for the triplet, doublet, and control arms, respectively. The progression-free survival times were 4.3, 4.2, and 1.5 months, respectively [104,105].

The combination of a MEK inhibitor and immunotherapy was associated with a satisfactory toxicity profile in $\mathrm{BRAF}^{\mathrm{V} 600 \mathrm{E}}$-mutant melanoma patients $[106,107]$. In a phase II trial of the triple combination of trametinib, dabrafenib, and pembrolizumab, the objective response rate was $63.3 \%$ (38 out of 60 patients with $\mathrm{BRAF}^{\mathrm{V} 600 \mathrm{E}}$-mutated advanced melanoma); 17 of these 38 patients $(44.7 \%)$ had ongoing responses [108].

\subsection{EGFR and PD-1 Inhibitors}

\subsubsection{EGFR-TKIs with a PD-1 Inhibitor}

Preclinical studies indicated that the activation of EGFR not only stimulated tumor growth but was positively correlated with the overexpression of PD-L1. Treatment of EGFR-mutant non-small cell lung cancer (NSCLC) cell lines with EGFR-TKIs decreased the expression of PD-1 and PD-L1 by inhibiting the NF-KB pathway [109-111]. These studies provided a theoretical basis for the combination treatment of EGFR-TKIs and immunotherapy. Haratani et al. reported that T790-negative patients with EGFR mutation-positive NSCLC were more likely to benefit from nivolumab after EGFR-TKI treatment [112]. This result was attributed to the fact that NSCLC patients with certain types of EGFR mutations may have a higher nonsynonymous mutation burden, such that they are more responsive to PD-1 inhibitors. However, it should be noted that the trial mainly included lung cancer patients rather than OSCC patients. OSCC is characterized by a higher tu- 
mor mutation burden, higher expression of PD-L1, and increased CD8+ T cell infiltration; therefore, OSCC patients can be expected to benefit more from combination treatment.

\subsubsection{EGFR-mAb with a PD-1 Inhibitor}

A multi-center phase II study investigating the combination of the EGFR-mAb cetuximab and PD-1 inhibitor pembrolizumab was conducted from 2017 to 2019. The study focused on recurrent and metastatic HNSCC; in 45\% of patients, the primary tumor site was in the oral cavity [113]. An overall response rate of $45 \%$ was achieved with combination therapy, which exceeded the response rates for pembrolizumab (16-18\%) and cetuximab (6-13\%) monotherapy [114]. We suggest that the resistance of cancer cells to cetuximab may be associated with a K-RAS mutation. The activation of the MAPK pathway enhanced the expression of PD-L1 and the infiltration of T cells and, thus, the response to immunotherapy. Although its mechanism of action is yet to be fully elucidated, this combination therapy has a promising future.

\section{Conclusions and Perspectives}

The use of two or more drugs for OSCC treatment inevitably leads to more severe side effects and immunotherapy can cause immune-related adverse events [115]. Therefore, combination therapy should be considered as an interim strategy while we wait for better treatments to be developed.

Recent studies aiming to characterize the interactions among the EMT, energy metabolism in cancer cells, immunity, and the TME have provided important results that should inform future research. By further exploring the components and sub-pathways of the MAPK, $\mathrm{PI} 3 \mathrm{~K} / \mathrm{AKT} / \mathrm{mTOR}$, and AMPK pathways, as well as their interactions with other pathways, we should be able to further improve evidence-based therapies of mAbs for treating OSCC.

Author Contributions: Conceptualization, T.K., Y.B., J.S. and T.O.; funding acquisition, T.K.; investigation, J.S. and Y.B.; methodology, Y.B., J.S., T.O., I.M., H.T., H.X.N. and T.K.; supervision, T.K.; visualization, Y.B., J.S., T.K. and T.O.; writing-original draft, Y.B. and J.S.; writing-review and editing, Y.B., J.S., T.O., I.M., H.T., H.X.N. and T.K.; Y.B. and J.S. equally contributed to this study and should be regarded as co-first authors. All authors have read and agreed to the published version of the manuscript.

Funding: This study did not receive any specific funding support; all financial resources were from the Department of Oral and Maxillofacial Surgery, Shimane University Faculty of Medicine.

Conflicts of Interest: The authors have no conflict of interest to declare.

\section{References}

1. Binmadi, N.O.; Basile, J.R. Perineural Invasion in Oral Squamous Cell Carcinoma: A Discussion of Significance and Review of the Literature. Oral Oncol. 2011, 47, 1005-1010. [CrossRef]

2. Vokes, E.E.; Weichselbaum, R.R.; Lippman, S.M.; Hong, W.K. Head and Neck Cancer. N. Engl. J. Med. 1993, 328, 184-194. [CrossRef] [PubMed]

3. Tong, X.; Tanino, R.; Sun, R.; Tsubata, Y.; Okimoto, T.; Takechi, M.; Isobe, T. Protein Tyrosine Kinase 2: A Novel Therapeutic Target to Overcome Acquired EGFR-TKI Resistance in Non-Small Cell Lung Cancer. Respir. Res. 2019, 20, 270. [CrossRef] [PubMed]

4. Xu, D.; Liu, S.; Zhang, L.; Song, L. MiR-211 Inhibits Invasion and Epithelial-to-Mesenchymal Transition (EMT) of Cervical Cancer Cells via Targeting MUC4. Biochem. Biophys. Res. Commun. 2017, 485, 556-562. [CrossRef] [PubMed]

5. Li, R.M.; Nai, M.M.; Duan, S.J.; Li, S.X.; Yin, B.N.; An, F.; Zhai, Y.Q.; Liu, J.; Chu, Y.R.; Yu, Y.; et al. Down-Expression of GOLM1 Enhances the Chemo-Sensitivity of Cervical Cancer to Methotrexate through Modulation of the MMP13/EMT Axis. Am. J. Cancer Res. 2018, 8, 964-980. Available online: https:/ / pubmed.ncbi.nlm.nih.gov/30034935/ (accessed on 23 November 2021). [PubMed]

6. Garg, M. Epithelial-Mesenchymal Transition-Activating Transcription Factors-Multifunctional Regulators in Cancer. World J. Stem Cells 2013, 5, 188-195. [CrossRef] [PubMed]

7. Xu, K. Tumor Metastasis; IntechOpen: London, UK, 2016; pp. 217-219.

8. Sha, J.; Bai, Y.; Ngo, H.X.; Okui, T.; Kanno, T. Overview of Evidence-Based Chemotherapy for OralCancer: Focus on Drug Resistance Related to the Epithelial-Mesenchymal Transition. Biomolecules 2021, 11, 893. [CrossRef] [PubMed]

9. Zhang, Q.; Chen, G.; Liu, X.; Qian, Q. Monoclonal Antibodies as Therapeutic Agents in Oncology and Antibody Gene Therapy. Cell Res. 2007, 17, 89-99. [CrossRef] [PubMed]

10. Scott, A.M.; Wolchok, J.D.; Old, L.J. Antibody Therapy of Cancer. Nat. Rev. Cancer 2012, 12, 278-287. [CrossRef] 
11. Schliemann, C.; Neri, D. Antibody-Based Targeting of the Tumor Vasculature. Biochim. Biophys. Acta 2007, 1776, 175-192. [CrossRef] [PubMed]

12. Hofmeister, V.; Vetter, C.; Schrama, D.; Bröcker, E.-B.; Becker, J.C. Tumor Stroma-Associated Antigens for Anti-Cancer Immunotherapy. Cancer Immunol. Immunother. 2006, 55, 481-494. [CrossRef]

13. Fulcher, C.D.; Haigentz, M.; Ow, T.J. Education Committee of the American Head and Neck Society (AHNS) AHNS Series: Do You Know Your Guidelines? Principles of Treatment for Locally Advanced or Unresectable Head and Neck Squamous Cell Carcinoma. Head Neck 2018, 40, 676-686. [CrossRef]

14. Craik, D.J.; Fairlie, D.P.; Liras, S.; Price, D. The Future of Peptide-Based Drugs. Chem. Biol. Drug Des. 2013, 81, 136-147. [CrossRef]

15. Mehra, R.; Seiwert, T.Y.; Gupta, S.; Weiss, J.; Gluck, I.; Eder, J.P.; Burtness, B.; Tahara, M.; Keam, B.; Kang, H.; et al. Efficacy and Safety of Pembrolizumab in Recurrent/Metastatic Head and Neck Squamous Cell Carcinoma: Pooled Analyses after Long-Term Follow-up in KEYNOTE-012. Br. J. Cancer 2018, 119, 153-159. [CrossRef] [PubMed]

16. Cunningham, D.; Humblet, Y.; Siena, S.; Khayat, D.; Bleiberg, H.; Santoro, A.; Bets, D.; Mueser, M.; Harstrick, A.; Verslype, C.; et al. Cetuximab Monotherapy and Cetuximab plus Irinotecan in Irinotecan-Refractory Metastatic Colorectal Cancer. N. Engl. J. Med. 2004, 351, 337-345. [CrossRef] [PubMed]

17. Roberts, P.J.; Der, C.J. Targeting the Raf-MEK-ERK Mitogen-Activated Protein Kinase Cascade for the Treatment of Cancer. Oncogene 2007, 26, 3291-3310. [CrossRef] [PubMed]

18. Vaklavas, C.; Forero-Torres, A. Safety and Efficacy of Brentuximab Vedotin in Patients with Hodgkin Lymphoma or Systemic Anaplastic Large Cell Lymphoma. Ther. Adv. Hematol. 2012, 3, 209-225. [CrossRef] [PubMed]

19. Ang, K.K.; Berkey, B.A.; Tu, X.; Zhang, H.-Z.; Katz, R.; Hammond, E.H.; Fu, K.K.; Milas, L. Impact of Epidermal Growth Factor Receptor Expression on Survival and Pattern of Relapse in Patients with Advanced Head and Neck Carcinoma. Cancer Res. 2002, 62, 7350-7356. Available online: https:/ / pubmed.ncbi.nlm.nih.gov/12499279/ (accessed on 23 November 2021).

20. Kagohara, L.T.; Zamuner, F.; Davis-Marcisak, E.F.; Sharma, G.; Considine, M.; Allen, J.; Yegnasubramanian, S.; Gaykalova, D.A.; Fertig, E.J. Integrated Single-Cell and Bulk Gene Expression and ATAC-Seq Reveals Heterogeneity and Early Changes in Pathways Associated with Resistance to Cetuximab in HNSCC-Sensitive Cell Lines. Br. J. Cancer 2020, 123, 101-113. [CrossRef]

21. Bai, Y.; Sha, J.; Kanno, T. The Role of Carcinogenesis-Related Biomarkers in the Wnt Pathway and Their Effects on EpithelialMesenchymal Transition (EMT) in Oral Squamous Cell Carcinoma. Cancers 2020, 12, 555. [CrossRef]

22. Liang, Z.; Brooks, J.; Willard, M.; Liang, K.; Yoon, Y.; Kang, S.; Shim, H. CXCR4/CXCL12 Axis Promotes VEGF-Mediated Tumor Angiogenesis through Akt Signaling Pathway. Biochem. Biophys. Res. Commun. 2007, 359, 716-722. [CrossRef]

23. Fusi, A.; Liu, Z.; Kümmerlen, V.; Nonnemacher, A.; Jeske, J.; Keilholz, U. Expression of Chemokine Receptors on Circulating Tumor Cells in Patients with Solid Tumors. J. Transl. Med. 2012, 10, 52. [CrossRef] [PubMed]

24. Chatterjee, S.; Azad, B.B.; Nimmagadda, S. The Intricate Role of CXCR4 in Cancer. Adv. Cancer Res. 2014, 124, 31-82. [CrossRef]

25. Xue, L.; Mao, X.; Ren, L.; Chu, X. Inhibition of CXCL12/CXCR4 Axis as a Potential Targeted Therapy of Advanced Gastric Carcinoma. Cancer Med. 2017, 6, 1424-1436. [CrossRef] [PubMed]

26. Guyon, A. CXCL12 Chemokine and Its Receptors as Major Players in the Interactions between Immune and Nervous Systems. Front. Cell. Neurosci. 2014, 8, 65. [CrossRef] [PubMed]

27. Fujiwara, T.; Eguchi, T.; Sogawa, C.; Ono, K.; Murakami, J.; Ibaragi, S.; Asaumi, J.-I.; Okamoto, K.; Calderwood, S.K.; Kozaki, K.-I. Anti-EGFR Antibody Cetuximab Is Secreted by Oral Squamous Cell Carcinoma and Alters EGF-Driven Mesenchymal Transition. Biochem. Biophys. Res. Commun. 2018, 503, 1267-1272. [CrossRef] [PubMed]

28. Yoshioka, M.; Ohashi, S.; Ida, T.; Nakai, Y.; Kikuchi, O.; Amanuma, Y.; Matsubara, J.; Yamada, A.; Miyamoto, S.; Natsuizaka, M.; et al. Distinct Effects of EGFR Inhibitors on Epithelial- and Mesenchymal-like Esophageal Squamous Cell Carcinoma Cells. J. Exp. Clin. Cancer Res. 2017, 36, 101. [CrossRef] [PubMed]

29. Andreu, Z.; Yáñez-Mó, M. Tetraspanins in Extracellular Vesicle Formation and Function. Front. Immunol. 2014, 5, 442. [CrossRef] [PubMed]

30. Ono, K.; Eguchi, T.; Sogawa, C.; Calderwood, S.K.; Futagawa, J.; Kasai, T.; Seno, M.; Okamoto, K.; Sasaki, A.; Kozaki, K.-I. HSP-Enriched Properties of Extracellular Vesicles Involve Survival of Metastatic Oral Cancer Cells. J. Cell. Biochem. 2018, 119, 7350-7362. [CrossRef]

31. Fujiwara, T.; Eguchi, T.; Sogawa, C.; Ono, K.; Murakami, J.; Ibaragi, S.; Asaumi, J.-I.; Calderwood, S.K.; Okamoto, K.; Kozaki, K.-I. Carcinogenic Epithelial-Mesenchymal Transition Initiated by Oral Cancer Exosomes Is Inhibited by Anti-EGFR Antibody Cetuximab. Oral Oncol. 2018, 86, 251-257. [CrossRef]

32. Vader, P. Extracellular Vesicle Heterogeneity: Subpopulations, Isolation Techniques, and Diverse Functions in Cancer Progression. Front. Immunol. 2018, 9, 738. [CrossRef]

33. Shin, D.M.; Donato, N.J.; Perez-Soler, R.; Shin, H.J.; Wu, J.Y.; Zhang, P.; Lawhorn, K.; Khuri, F.R.; Glisson, B.S.; Myers, J.; et al. Epidermal Growth Factor Receptor-Targeted Therapy with C225 and Cisplatin in Patients with Head and Neck Cancer. Clin. Cancer Res. 2001, 7, 1204-1213. Available online: https:/ / pubmed.ncbi.nlm.nih.gov/11350885/ (accessed on 23 November 2021). [PubMed]

34. Downward, J.; Parker, P.; Waterfield, M.D. Autophosphorylation Sites on the Epidermal Growth Factor Receptor. Nature 1984, 311, 483-485. [CrossRef] [PubMed]

35. Benhar, M.; Dalyot, I.; Engelberg, D.; Levitzki, A. Enhanced ROS Production in Oncogenically Transformed Cells Potentiates C-Jun N-Terminal Kinase and P38 Mitogen-Activated Protein Kinase Activation and Sensitization to Genotoxic Stress. Mol. Cell. Biol. 2001, 21, 6913-6926. [CrossRef] 
36. Gan, D.; He, W.; Yin, H.; Gou, X. $\beta$-Elemene Enhances Cisplatin-Induced Apoptosis in Bladder Cancer Cells through the ROS-AMPK Signaling Pathway. Oncol. Lett. 2020, 19, 291-300. [CrossRef] [PubMed]

37. Li, X.; Lu, Y.; Lu, H.; Luo, J.; Hong, Y.; Fan, Z. AMPK-Mediated Energy Homeostasis and Associated Metabolic Effects on Cancer Cell Response and Resistance to Cetuximab. Oncotarget 2015, 6, 11507-11518. [CrossRef] [PubMed]

38. Karapetis, C.S.; Tu, D.; Robitaille, S.; Price, T.J.; Langer, C. K-Ras Mutations and Benefit from Cetuximab in Advanced Colorectal Cancer. N. Engl. J. Med. 2008, 359, 1757-1765. [CrossRef]

39. Krishna, A.; Singh, S.; Singh, V.; Kumar, V.; Singh, U.S.; Sankhwar, S.N. Does Harvey-Ras Gene Expression Lead to Oral Squamous Cell Carcinoma? A Clinicopathological Aspect. J. Oral Maxillofac. Pathol. 2018, 22, 65-72. [CrossRef] [PubMed]

40. Usman, S.; Jamal, A.; The, M.T.; Waseem, A. Major Molecular Signaling Pathways in Oral Cancer Associated With Therapeutic Resistance. Front. Oral Health 2021, 1, 19. [CrossRef]

41. Hah, J.H.; Zhao, M.; Pickering, C.R.; Frederick, M.J.; Andrews, G.A.; Jasser, S.A.; Fooshee, D.R.; Milas, Z.L.; Galer, C.; Sano, D.; et al. HRAS Mutations and Resistance to the Epidermal Growth Factor Receptor Tyrosine Kinase Inhibitor Erlotinib in Head and Neck Squamous Cell Carcinoma Cells. Head Neck 2014, 36, 1547-1554. [CrossRef] [PubMed]

42. Ye, H.; Liu, Y.; Wu, F.; Luo, H.; Cui, L. AMPK Activation Overcomes Anti-EGFR Antibody Resistance Induced by KRAS Mutation in Colorectal Cancer. Cell Commun. Signal. 2020, 18, 115. [CrossRef] [PubMed]

43. Hsu, P.P.; Sabatini, D.M. Cancer Cell Metabolism: Warburg and Beyond. Cell 2008, 134, 703-707. [CrossRef] [PubMed]

44. Christofk, H.R.; Vander Heiden, M.G.; Harris, M.H.; Ramanathan, A.; Gerszten, R.E.; Wei, R.; Fleming, M.D.; Schreiber, S.L.; Cantley, L.C. The M2 Splice Isoform of Pyruvate Kinase Is Important for Cancer Metabolism and Tumour Growth. Nature 2008, 452, 230-233. [CrossRef] [PubMed]

45. Lin, C.-C.; Cheng, T.-L.; Tsai, W.-H.; Tsai, H.-J.; Hu, K.-H.; Chang, H.-C.; Yeh, C.-W.; Chen, Y.-C.; Liao, C.-C.; Chang, W.-T. Loss of the Respiratory Enzyme Citrate Synthase Directly Links the Warburg Effect to Tumor Malignancy. Sci. Rep. 2012, 2, 785. [CrossRef]

46. Gilardi, M.; Wang, Z.; Proietto, M.; Chillà, A.; Calleja-Valera, J.L.; Goto, Y.; Vanoni, M.; Janes, M.R.; Mikulski, Z.; Gualberto, A.; et al. Tipifarnib as a Precision Therapy for HRAS-Mutant Head and Neck Squamous Cell Carcinomas. Mol. Cancer Ther. 2020, 19, 1784-1796. [CrossRef] [PubMed]

47. Hanahan, D.; Weinberg, R.A. Hallmarks of Cancer: The Next Generation. Cell 2011, 144, 646-674. [CrossRef] [PubMed]

48. Sharpe, A.H.; Freeman, G.J. The B7-CD28 Superfamily. Nat. Rev. Immunol. 2002, 2, 116-126. Available online: https://www. nature.com/articles/nri727 (accessed on 23 November 2021). [CrossRef]

49. Freeman, G.J.; Long, A.J.; Iwai, Y.; Bourque, K.; Chernova, T.; Nishimura, H.; Fitz, L.J.; Malenkovich, N.; Okazaki, T.; Byrne, M.C.; et al. Engagement of the PD-1 Immunoinhibitory Receptor by a Novel B7 Family Member Leads to Negative Regulation of Lymphocyte Activation. J. Exp. Med. 2000, 192, 1027-1034. [CrossRef]

50. Garon, E.B.; Leighl, N.; Patnaik, A.; Horn, L.; Felip, E.; Hamid, O.; Dolled-Filhart, M.; Lunceford, J.K.; Roach, C.; Gandhi, L. Pembrolizumab for the Treatment of Non-Small-Cell Lung Cancer. N. Engl. J. Med. 2015, 372, 2018-2028. [CrossRef]

51. Syn, N.L.; Teng, M.W.L.; Mok, T.S.K.; Soo, R.A. De-Novo and Acquired Resistance to Immune Checkpoint Targeting. Lancet Oncol. 2017, 18, e731-e741. [CrossRef]

52. Sundar, R.; Cho, B.-C.; Brahmer, J.R.; Soo, R.A. Nivolumab in NSCLC: Latest Evidence and Clinical Potential. Ther. Adv. Med. Oncol. 2015, 7, 85-96. [CrossRef]

53. Elias, R.; Karantanos, T.; Sira, E.; Hartshorn, K.L. Immunotherapy Comes of Age: Immune Aging \& Checkpoint Inhibitors. J. Geriatr. Oncol. 2017, 8, 229-235. [CrossRef] [PubMed]

54. Cui, P.; Li, R.; Huang, Z.; Wu, Z.; Tao, H.; Zhang, S.; Hu, Y. Comparative Effectiveness of Pembrolizumab vs. Nivolumab in Patients with Recurrent or Advanced NSCLC. Sci. Rep. 2020, 10, 13160. [CrossRef] [PubMed]

55. Fessas, P.; Lee, H.; Ikemizu, S.; Janowitz, T. A Molecular and Preclinical Comparison of the PD-1-Targeted T cell Checkpoint Inhibitors Nivolumab and Pembrolizumab. Semin. Oncol. 2017, 44, 136-140. [CrossRef] [PubMed]

56. Prasad, V.; Kaestner, V. Nivolumab and Pembrolizumab: Monoclonal Antibodies against Programmed Cell Death-1 (PD-1) That Are Interchangeable. Semin. Oncol. 2017, 44, 132-135. [CrossRef] [PubMed]

57. Zou, W.; Wolchok, J.D.; Chen, L. PD-L1 (B7-H1) and PD-1 Pathway Blockade for Cancer Therapy: Mechanisms, Response Biomarkers, and Combinations. Sci. Transl. Med. 2016, 8, 328rv4. [CrossRef]

58. Kumar, A.; Chamoto, K. Immune Metabolism in PD-1 Blockade-Based Cancer Immunotherapy. Int. Immunol. 2021, 33, 17-26. [CrossRef] [PubMed]

59. Chamoto, K.; Hatae, R.; Honjo, T. Current Issues and Perspectives in PD-1 Blockade Cancer Immunotherapy. Int. J. Clin. Oncol. 2020, 25, 790-800. [CrossRef]

60. Lou, Y.; Diao, L.; Cuentas, E.R.P.; Denning, W.L.; Chen, L.; Fan, Y.H.; Byers, L.A.; Wang, J.; Papadimitrakopoulou, V.A.; Behrens, C.; et al. Epithelial-Mesenchymal Transition Is Associated with a Distinct Tumor Microenvironment Including Elevation of Inflammatory Signals and Multiple Immune Checkpoints in Lung Adenocarcinoma. Clin. Cancer Res. 2016, 22, 3630-3642. [CrossRef]

61. Datar, I.; Schalper, K.A. Epithelial-Mesenchymal Transition and Immune Evasion during Lung Cancer Progression: The Chicken or the Egg? Clin. Cancer Res. 2016, 22, 3422-3424. [CrossRef]

62. Puisieux, A.; Brabletz, T.; Caramel, J. Oncogenic Roles of EMT-Inducing Transcription Factors. Nat. Cell Biol. 2014, 16, 488-494. [CrossRef] [PubMed] 
63. Qian, Y.; Yao, W.; Yang, T.; Yang, Y.; Liu, Y.; Shen, Q.; Zhang, J.; Qi, W.; Wang, J. APKC-ı/P-Sp1/Snail Signaling Induces EpithelialMesenchymal Transition and Immunosuppression in Cholangiocarcinoma. Hepatology 2017, 66, 1165-1182. [CrossRef] [PubMed]

64. Ye, L.-Y.; Chen, W.; Bai, X.-L.; Xu, X.-Y.; Zhang, Q.; Xia, X.-F.; Sun, X.; Li, G.-G.; Hu, Q.-D.; Fu, Q.-H.; et al. Hypoxia-Induced Epithelial-to-Mesenchymal Transition in Hepatocellular Carcinoma Induces an Immunosuppressive Tumor Microenvironment to Promote Metastasis. Cancer Res. 2016, 76, 818-830. [CrossRef]

65. Kudo-Saito, C.; Shirako, H.; Ohike, M.; Tsukamoto, N.; Kawakami, Y. CCL2 Is Critical for Immunosuppression to Promote Cancer Metastasis. Clin. Exp. Metastasis 2013, 30, 393-405. [CrossRef] [PubMed]

66. Cao, Y.; Zhang, L.; Kamimura, Y.; Ritprajak, P.; Hashiguchi, M.; Hirose, S.; Azuma, M. B7-H1 Overexpression Regulates Epithelial-Mesenchymal Transition and Accelerates Carcinogenesis in Skin. Cancer Res. 2011, 71, 1235-1243. [CrossRef] [PubMed]

67. Sharif, M.N.; Šošic, D.; Rothlin, C.V.; Kelly, E.; Lemke, G.; Olson, E.N.; Ivashkiv, L.B. Twist Mediates Suppression of Inflammation by Type I IFNs and Axl. J. Exp. Med. 2006, 203, 1891-1901. [CrossRef] [PubMed]

68. Goossens, S.; Vandamme, N.; Van Vlierberghe, P.; Berx, G. EMT Transcription Factors in Cancer Development Re-Evaluated: Beyond EMT and MET. Biochim. Biophys. Acta Rev. Cancer 2017, 1868, 584-591. [CrossRef]

69. Nieto, M.A.; Huang, R.Y.-J.; Jackson, R.A.; Thiery, J.P. EMT: 2016. Cell 2016, 166, 21-45. [CrossRef]

70. Diepenbruck, M.; Christofori, G. Epithelial-Mesenchymal Transition (EMT) and Metastasis: Yes, No, Maybe? Curr. Opin. Cell Biol. 2016, 43, 7-13. [CrossRef]

71. Jones, R.G.; Thompson, C.B. Revving the Engine: Signal Transduction Fuels T Cell Activation. Immunity 2007, 27, 173-178. [CrossRef] [PubMed]

72. Chang, C.-H.; Qiu, J.; O'Sullivan, D.; Buck, M.D.; Noguchi, T.; Curtis, J.D.; Chen, Q.; Gindin, M.; Gubin, M.M.; van der Windt, G.J.W.; et al. Metabolic Competition in the Tumor Microenvironment Is a Driver of Cancer Progression. Cell 2015, 162, 1229-1241. [CrossRef] [PubMed]

73. Ho, P.-C.; Bihuniak, J.D.; Macintyre, A.N.; Staron, M.; Liu, X.; Amezquita, R.; Tsui, Y.-C.; Cui, G.; Micevic, G.; Perales, J.C.; et al. Phosphoenolpyruvate Is a Metabolic Checkpoint of Anti-Tumor T Cell Responses. Cell 2015, 162, 1217-1228. [CrossRef] [PubMed]

74. Brand, A.; Singer, K.; Koehl, G.E.; Kolitzus, M.; Schoenhammer, G.; Thiel, A.; Matos, C.; Bruss, C.; Klobuch, S.; Peter, K.; et al. LDHAAssociated Lactic Acid Production Blunts Tumor Immunosurveillance by T and NK Cells. Cell Metab. 2016, 24, 657-671. [CrossRef]

75. Inoki, K.; Kim, J.; Guan, K.-L. AMPK and MTOR in Cellular Energy Homeostasis and Drug Targets. Annu. Rev. Pharmacol. Toxicol. 2012, 52, 381-400. [CrossRef] [PubMed]

76. Patsoukis, N.; Bardhan, K.; Weaver, J.; Herbel, C.; Seth, P.; Li, L.; Boussiotis, V.A. The Role of Metabolic Reprogramming in T Cell Fate and Function. Curr. Trends Immunol. 2016, 17, 1-12. Available online: https:/ / pubmed.ncbi.nlm.nih.gov/28356677/ (accessed on 23 November 2021).

77. Xu, J.; Ji, J.; Yan, X.-H. Cross-Talk between AMPK and MTOR in Regulating Energy Balance. Crit. Rev. Food Sci. Nutr. 2012, 52, 373-381. [CrossRef]

78. Zhang, Q.; Zhang, Y.; Chen, Y.; Qian, J.; Zhang, X.; Yu, K. A Novel MTORC1/2 Inhibitor (MTI-31) Inhibits Tumor Growth, Epithelial-Mesenchymal Transition, Metastases, and Improves Antitumor Immunity in Preclinical Models of Lung Cancer. Clin. Cancer Res. 2019, 25, 3630-3642. [CrossRef] [PubMed]

79. Pan, L.-N.; Ma, Y.-F.; Li, Z.; Hu, J.-A.; Xu, Z.-H. KRAS G12V Mutation Upregulates PD-L1 Expression via TGF- $\beta$ /EMT Signaling Pathway in Human Non-Small-Cell Lung Cancer. Cell Biol. Int. 2021, 45, 795-803. [CrossRef] [PubMed]

80. Coulson, A.; Levy, A.; Gossell-Williams, M. Monoclonal Antibodies in Cancer Therapy: Mechanisms, Successes and Limitations. West Indian Med. J. 2014, 63, 650-654. [CrossRef]

81. Hiraishi, Y.; Wada, T.; Nakatani, K.; Negoro, K.; Fujita, S. Immunohistochemical Expression of EGFR and P-EGFR in Oral Squamous Cell Carcinomas. Pathol. Oncol. Res. 2006, 12, 87-91. [CrossRef]

82. Salomon, D.S.; Brandt, R.; Ciardiello, F.; Normanno, N. Epidermal Growth Factor-Related Peptides and Their Receptors in Human Malignancies. Crit. Rev. Oncol. Hematol. 1995, 19, 183-232. [CrossRef]

83. Moskowitz, H.S.; Gooding, W.E.; Thomas, S.M.; Freilino, M.L.; Gross, N.; Argiris, A.; Grandis, J.R.; Ferris, R.L. Serum Biomarker Modulation Following Molecular Targeting of Epidermal Growth Factor and Cyclooxygenase Pathways: A Pilot Randomized Trial in Head and Neck Cancer. Oral Oncol. 2012, 48, 1136-1145. [CrossRef] [PubMed]

84. Concu, R.; Cordeiro, M.N.D.S. Cetuximab and the Head and Neck Squamous Cell Cancer. Curr. Top Med. Chem. 2018, 18, 192-198. [CrossRef]

85. Shaib, W.; Kono, S.; Saba, N. Antiepidermal Growth Factor Receptor Therapy in Squamous Cell Carcinoma of the Head and Neck. J. Oncol. 2012, 2012, 521215. [CrossRef] [PubMed]

86. Pao, W.; Miller, V.A.; Politi, K.A.; Riely, G.J.; Somwar, R.; Zakowski, M.F.; Kris, M.G.; Varmus, H. Acquired Resistance of Lung Adenocarcinomas to Gefitinib or Erlotinib Is Associated with a Second Mutation in the EGFR Kinase Domain. PLoS Med. 2005, 2, e73. [CrossRef]

87. Chow, L.Q.M.; Haddad, R.; Gupta, S.; Mahipal, A.; Mehra, R.; Tahara, M.; Berger, R.; Eder, J.P.; Burtness, B.; Lee, S.-H.; et al. Antitumor Activity of Pembrolizumab in Biomarker-Unselected Patients With Recurrent and/or Metastatic Head and Neck Squamous Cell Carcinoma: Results From the Phase Ib KEYNOTE-012 Expansion Cohort. J. Clin. Oncol. 2016, 34, 3838-3845. [CrossRef]

88. Warnakulasuriya, S. Global Epidemiology of Oral and Oropharyngeal Cancer. Oral Oncol. 2009, 45, 309-316. [CrossRef]

89. Rogers, S.N.; Vedpathak, S.V.; Lowe, D. Reasons for Delayed Presentation in Oral and Oropharyngeal Cancer: The Patients Perspective. Br. J. Oral Maxillofac. Surg. 2011, 49, 349-353. [CrossRef] [PubMed] 
90. Dunkel, J. Heterogeneity of Oral Cavity Cancer with Special Attention to Immune Function of Clever. 2017. Available online: https: / / www.utupub.fi/bitstream/handle/10024/134551/AnnalesD1281Dunkel.pdf?sequence=2 (accessed on 23 November 2021).

91. Yunpeng, B.; Nakatani, E.; Iwahashi, T.; Tabuchi, Y.; Nariai, Y.; Karino, M.; Kanno, T.; Yongqing, H.; Kagimura, T.; Vieth, M.; et al. Clinical Investigation Into the Prevalence and Associated Factors for Second Primary Tumor of the Esophagus in Oral Tumor Patients. Shimane J. Med. Sci. 2016, 32, 81-88. Available online: https:/ /www.semanticscholar.org/paper/Clinical-InvestigationInto-the-Prevalence-and-for-Bai-Nakatani/c51cb0c88d62d970b05e0dd3fd9a6854800dcdda (accessed on 23 November 2021).

92. Culmsee, C.; Monnig, J.; Kemp, B.E.; Mattson, M.P. AMP-Activated Protein Kinase Is Highly Expressed in Neurons in the Developing Rat Brain and Promotes Neuronal Survival Following Glucose Deprivation. J. Mol. Neurosci. 2001, 17, 45-58. [CrossRef]

93. Towler, M.C.; Hardie, D.G. AMP-Activated Protein Kinase in Metabolic Control and Insulin Signaling. Circ. Res. 2007, 100, 328-341. [CrossRef] [PubMed]

94. Herzig, S.; Shaw, R.J. AMPK: Guardian of Metabolism and Mitochondrial Homeostasis. Nat. Rev. Mol. Cell Biol. 2018, 19, 121-135. [CrossRef] [PubMed]

95. Xu, Y.; Li, N.; Xiang, R.; Sun, P. Emerging Roles of the P38 MAPK and PI3K/AKT/MTOR Pathways in Oncogene-Induced Senescence. Trends Biochem. Sci. 2014, 39, 268-276. [CrossRef] [PubMed]

96. Ashwell, J.D. The Many Paths to P38 Mitogen-Activated Protein Kinase Activation in the Immune System. Nat. Rev. Immunol. 2006, 6, 532-540. [CrossRef] [PubMed]

97. Chang, L.; Karin, M. Mammalian MAP Kinase Signalling Cascades. Nature 2001, 410, 37-40. [CrossRef] [PubMed]

98. Wang, W.; Chen, J.X.; Liao, R.; Deng, Q.; Zhou, J.J.; Huang, S.; Sun, P. Sequential Activation of the MEK-Extracellular SignalRegulated Kinase and MKK3/6-P38 Mitogen-Activated Protein Kinase Pathways Mediates Oncogenic Ras-Induced Premature Senescence. Mol. Cell. Biol. 2002, 22, 3389-3403. [CrossRef]

99. Peng, Q.; Deng, Z.; Pan, H.; Gu, L.; Liu, O.; Tang, Z. Mitogen-Activated Protein Kinase Signaling Pathway in Oral Cancer. Oncol. Lett. 2018, 15, 1379-1388. [CrossRef]

100. Eikawa, S.; Nishida, M.; Mizukami, S.; Yamazaki, C.; Nakayama, E.; Udono, H. Immune-Mediated Antitumor Effect by Type 2 Diabetes Drug, Metformin. Proc. Natl. Acad. Sci. USA 2015, 112, 1809-1814. [CrossRef] [PubMed]

101. Han, J.; Liu, Y.; Yang, S.; Wu, X.; Li, H.; Wang, Q. MEK Inhibitors for the Treatment of Non-Small Cell Lung Cancer. J. Hematol. Oncol. 2021, 14, 1. [CrossRef]

102. Barrett, S.D.; Bridges, A.J.; Dudley, D.T.; Saltiel, A.R.; Fergus, J.H.; Flamme, C.M.; Delaney, A.M.; Kaufman, M.; LePage, S.; Leopold, W.R.; et al. The Discovery of the Benzhydroxamate MEK Inhibitors CI-1040 and PD 0325901. Bioorg. Med. Chem. Lett. 2008, 18, 6501-6504. [CrossRef]

103. El-Hoss, J.; Kolind, M.; Jackson, M.T.; Deo, N.; Mikulec, K.; McDonald, M.M.; Little, C.B.; Little, D.G.; Schindeler, A. Modulation of Endochondral Ossification by MEK Inhibitors PD0325901 and AZD6244 (Selumetinib). Bone 2014, 59, 151-161. [CrossRef] [PubMed]

104. Gandara, D.R.; Leighl, N.; Delord, J.-P.; Barlesi, F.; Bennouna, J.; Zalcman, G.; Infante, J.R.; Reckamp, K.L.; Kelly, K.; Shepherd, F.A.; et al. A Phase 1/1b Study Evaluating Trametinib Plus Docetaxel or Pemetrexed in Patients With Advanced Non-Small Cell Lung Cancer. J. Thorac. Oncol. 2017, 12, 556-566. [CrossRef] [PubMed]

105. Kopetz, S.; Grothey, A.; Yaeger, R.; Van Cutsem, E.; Desai, J.; Yoshino, T.; Wasan, H.; Ciardiello, F.; Loupakis, F.; Hong, Y.S.; et al. Encorafenib, Binimetinib, and Cetuximab in BRAF V600E-Mutated Colorectal Cancer. N. Engl. J. Med. 2019, 381, 1632-1643. [CrossRef] [PubMed]

106. Ma, W.; Gilligan, B.M.; Yuan, J.; Li, T. Current Status and Perspectives in Translational Biomarker Research for PD-1/PD-L1 Immune Checkpoint Blockade Therapy. J. Hematol. Oncol. 2016, 9, 47. [CrossRef]

107. Diggs, L.P.; Hsueh, E.C. Utility of PD-L1 Immunohistochemistry Assays for Predicting PD-1/PD-L1 Inhibitor Response. Biomark Res. 2017, 5, 12. [CrossRef]

108. Dongre, A.; Rashidian, M.; Reinhardt, F.; Bagnato, A.; Keckesova, Z.; Ploegh, H.L.; Weinberg, R.A. Epithelial-to-Mesenchymal Transition Contributes to Immunosuppression in Breast Carcinomas. Cancer Res. 2017, 77, 3982-3989. [CrossRef]

109. Liang, H.; Liu, X.; Wang, M. Immunotherapy Combined with Epidermal Growth Factor Receptor-Tyrosine Kinase Inhibitors in Non-Small-Cell Lung Cancer Treatment. Onco Targets Ther. 2018, 11, 6189-6196. [CrossRef] [PubMed]

110. Azuma, K.; Ota, K.; Kawahara, A.; Hattori, S.; Iwama, E.; Harada, T.; Matsumoto, K.; Takayama, K.; Takamori, S.; Kage, M.; et al. Association of PD-L1 Overexpression with Activating EGFR Mutations in Surgically Resected Nonsmall-Cell Lung Cancer. Ann. Oncol. 2014, 25, 1935-1940. [CrossRef]

111. Lin, K.; Cheng, J.; Yang, T.; Li, Y.; Zhu, B. EGFR-TKI down-Regulates PD-L1 in EGFR Mutant NSCLC through Inhibiting NF-KB. Biochem. Biophys. Res. Commun. 2015, 463, 95-101. [CrossRef]

112. Haratani, K.; Hayashi, H.; Tanaka, T.; Kaneda, H.; Togashi, Y.; Sakai, K.; Hayashi, K.; Tomida, S.; Chiba, Y.; Yonesaka, K.; et al. Tumor Immune Microenvironment and Nivolumab Efficacy in EGFR Mutation-Positive Non-Small-Cell Lung Cancer Based on T790M Status after Disease Progression during EGFR-TKI Treatment. Ann. Oncol. 2017, 28, 1532-1539. [CrossRef]

113. Sacco, A.G.; Chen, R.; Worden, F.P.; Wong, D.J.L.; Adkins, D.; Swiecicki, P.; Chai-Ho, W.; Oppelt, P.; Ghosh, D.; Bykowski, J.; et al. Pembrolizumab plus Cetuximab in Patients with Recurrent or Metastatic Head and Neck Squamous Cell Carcinoma: An Open-Label, Multi-Arm, Non-Randomised, Multicentre, Phase 2 Trial. Lancet Oncol. 2021, 22, 883-892. [CrossRef] 
114. Cohen, E.E.W.; Soulières, D.; Tourneau, C.L.; Dinis, J.; Licitra, L.; Ahn, M.-J.; Soria, A.; Machiels, J.-P.; Mach, N.; Mehra, R.; et al. Pembrolizumab versus Methotrexate, Docetaxel, or Cetuximab for Recurrent or Metastatic Head-and-Neck Squamous Cell Carcinoma (KEYNOTE-040): A Randomised, Open-Label, Phase 3 Study. Lancet 2019, 393, 156-167. [CrossRef]

115. Ramos-Casals, M.; Brahmer, J.R.; Callahan, M.K.; Flores-Chávez, A.; Keegan, N.; Khamashta, M.A.; Lambotte, O.; Mariette, X.; Prat, A.; Suárez-Almazor, M.E. Immune-Related Adverse Events of Checkpoint Inhibitors. Nat. Rev. Dis. Primers 2020, 6, 38. [CrossRef] [PubMed] 